\title{
REDUCED GLASS-TRANSITION TEMPERATURE VERSUS GLASS-FORMING ABILITY IN FeCOB-BASED AMORPHOUS ALLOYS
}

\begin{abstract}
This work presents studies concerning the relationship between reduction of glass transition temperature $T_{r g}$ and the glass-forming ability of $\mathrm{FeCoB}$-based alloys. On the basis of theoretical considerations, Turnbull [1] determined the reduced glass transition temperature $\left(T_{g} / T_{l}\right)$ as being $2 / 3$ of the Vogel-Fulcher-Tammann (VFT) temperature; since then, continuous research has been carried out, aiming to calculate the Trg parameter and describe its relationship with glass-forming ability. In the majority of research papers, the reduced glass transition temperature is calculated from the relationship $T_{g} / T_{m}$, proposed by Uhlmann and Davies $[2,3]$. On the basis of differential scanning calorimetry (DSC) studies, undertaken in this current work, the values of the following temperatures have been found: $T_{g}, T_{x}, \mathrm{Tm}$ and $\mathrm{Tl}$, in addition to the temperature ranges: $\Delta T_{x}, \Delta T_{m}$ and $\Delta T_{l}$. The correlation between: $T_{g} / T_{m}, T_{g} / T_{l}$ and the glass-forming ability also has been discussed. Finally, for the investigated alloys, it has been found that the relationship proposed by Turnbull is reliable over a wide range of $\Delta T_{m}$.

Keywords: glass-transition temperature, bulk amorphous alloy, glass-forming ability
\end{abstract}

\section{Introduction}

Given the constant need for new materials, targetting a multitude of applications, many research facilities are looking to develop such materials with specific properties. The FeCoB-based amorphous materials make up one such group of 'functional materials' which feature very promising properties [4-7]. These materials can be produced as ferromagnetic alloys, featuring very good so-called soft magnetic properties [8-13]. The potential for these particular materials is enormous due to their application in electrical devices. One of the first bulk metallic alloys featuring an amorphous structure was developed by Turnbull [14]. The amorphous samples were produced using a melt-spinning technique. This method involves the quenching of a 'jet' of the molten alloy on a rotating copper wheel [15]. Over the course of numerous experiments, it has been noticed that obtaining an amorphous structure in alloys is a very difficult task. As a result, research into the parameters of the glass-forming ability of the alloys has been undertaken.

It is well known that for the majority of liquids, their crystallisation occurs below the melting temperature Tm, when the migrating atoms are mobile enough to create repeating patterns in the volume configurations with the same elementary cell and the conservation of angular translation. In this case, the cause of the crystallisation is a difference in the values of the free-energy between the liquid and crystalline phases; this becomes the driving force required for nucleation of the crystalline structure. In the case of a liquid with high glass-forming ability, below the temperature $\mathrm{Tm}$, a supercooled liquid can be obtained; as a result of further cooling, at an appropriate cooling rate, this liquid can become a solid with an amorphous structure. The vitrification of the alloy occurs at the characteristic temperature called the glasstransition temperature, $T g$, which actually is a very narrow range of temperatures rather than a discrete value. During the glass-transition process, a division surface is created, which is directly related to the positive surface energy; this is a nucleation barrier. According to theory, the rate of homogeneous nucleation $I v$ (per volume unit) is connected to the viscosity and diffusion. The rate of the atomic migration can be described as [16]:

$$
I_{v}=\frac{A v}{\eta(T)} \exp \left(-\frac{\Delta G^{*}}{k_{B} T}\right)
$$

where:

$A v$ - constant of the order of $10^{32} \mathrm{~Pa} \cdot \mathrm{s} / \mathrm{m}^{3} \mathrm{~s}$,

$k_{B}$ - Boltzmann constant,

$\Delta G^{*}=(16 / 3) \pi \sigma^{3} /[\Delta g(T)]^{2}$ - the nucleation barrier for spherical nuclei,

$\Delta g$ - the free volume difference (per volume unit),

$\sigma$ - the interphase energy between liquid and nuclei.

The kinetic parameters influencing the ability to form a material with an amorphous structure are viscosity and diffusion coefficient. These parameters are related by the Stokes-Einstein relation [17]:

$$
D=k_{B} T /(3 \pi \eta l)
$$

where :

$l$ - atomic diameter (average).

The viscosity is commonly described using the modified

\footnotetext{
* CZESTOCHOWA UNIVERSITY OF TECHNOLOGY, INSTITUTE OF PHYSICS, 19 ARMII KRAJOWEJ AV., 42-200 CZESTOCHOWA, POLAND

* Corresponding author: nmarcell@wp.pl
} 
Vogel - Fulcher - Tammann relationship (VFT) [18]:

$$
\eta(T)=\eta_{0} \exp \frac{D^{*} T_{0}}{T-T_{0}}
$$

where:

$D^{*}$ - sensitivity parameter $\left(1 \leq D^{*} \leq 100\right)$,

$T_{0}$ - Vogel-Fulcher-Tammann temperature (VFT),

$\eta_{0}$ - constant - in inverse proportion to the molar volume of the liquid.

The VFT temperature corresponds to the value of temperature at which the value of the viscosity of the liquid increases to infinity. The $D^{*}$ parameter is the degree of disagreement of the liquid viscosity with the Arrhenius law. For pure metals, the value of $D^{*}$ is close to 1 , but for $\mathrm{SiO}_{2}$, it is equal to 100 . For $D^{*}=100$, the viscosity of $\mathrm{SiO}_{2}$ fulfils the Arrhenius temperature relationship.

Taking the aforementioned details into account, it could be stated that the liquid temperature, VTF temperature, and sensitivity parameter are deciding factors in the nucleation process. Using generalised descriptions: $\mathrm{Tr}=\mathrm{T} / \mathrm{Tl}, \mathrm{Tr} 0=\mathrm{T} 0 / \mathrm{T}$ and $A=16 \pi \sigma^{3} /\left(3 k_{B} \alpha^{2} T_{l}^{3} \Delta s_{f}^{2}\right)$, the rate of nucleation could be described using the following relationship [18]:

$$
I_{v}=\frac{A_{v}}{\eta_{0}} \exp \left(-\frac{D^{*} T_{r 0}}{T_{r}-T_{r 0}}\right) \exp \left(-\frac{A}{T_{r}\left(1-T_{r}\right)^{2}}\right)
$$

Over the range of $\operatorname{Tr} 0<\operatorname{Tr}<1$, with an increase in supercooling, the value of the first exponential term is rapidly decreasing while the value of the second exponential term is rapidly increasing. Therefore, the maximum rate of nucleation is increased at the median value of supercooling. The higher the value of the VFT temperature, the higher the value of the dumping of the nucleation rate. At a lower liquid temperature, due to the increased value of the A parameter, the second exponential term increases gently with supercooling. This dependency was noticed by Turnbull in the 1960s. At this time, it was assumed that the VFT temperature is equal to $\operatorname{Tr} g$ and Turnbull replaced the reduced VFT temperature by the reduced glass transition temperature. The most important thing which was found it is that the homegeneous nucleation is suppressed for $\operatorname{Tr} g \geq 2 / 3$. As was shown in [19], and in many other research publications, in order to calculate the value of $\operatorname{Trg}$, the values of $T m$ and $T l$, and even $T g$ and $T x$ are being used interchangeably. Therefore this issue is a subject of this work. In general, as indicated by the abovementioned discussion, the correct notation of $\operatorname{Trg}$ should be related to the ratio $T l / T g$.

In this work, the comparison of technical parameters of the FeCoB- based alloys is presented.

\section{Experiment}

All of the investigated samples were produced using a process of rapid solidification. For the purpose of this work, data were used for samples which were made using the same production method. The analysed samples were produced in the form of bulk plates of approximate thickness $0.5 \mathrm{~mm}$, using the suction-casting method. The molten alloy was rapidly quenched in a copper-die, under a protective atmosphere of neutral gas (Ar). Following this production process, the structure of the alloys was investigated using a Bruker Advance D8 X-ray diffractometer (featuring a $\mathrm{CuK} \alpha$ source).

Measurement of the heat flow, as a function of temperature, was performed using differential scanning calorimetery (DSC). The samples were heated from room temperature to the liquid temperature $T l$ at a constant rate of $10 \mathrm{~K} / \mathrm{min}$. The DSC measurements were performed under the Ar atmosphere.

\section{Results and discussion}

The X-ray diffraction patterns for the analysed samples are presented in Fig. 1.

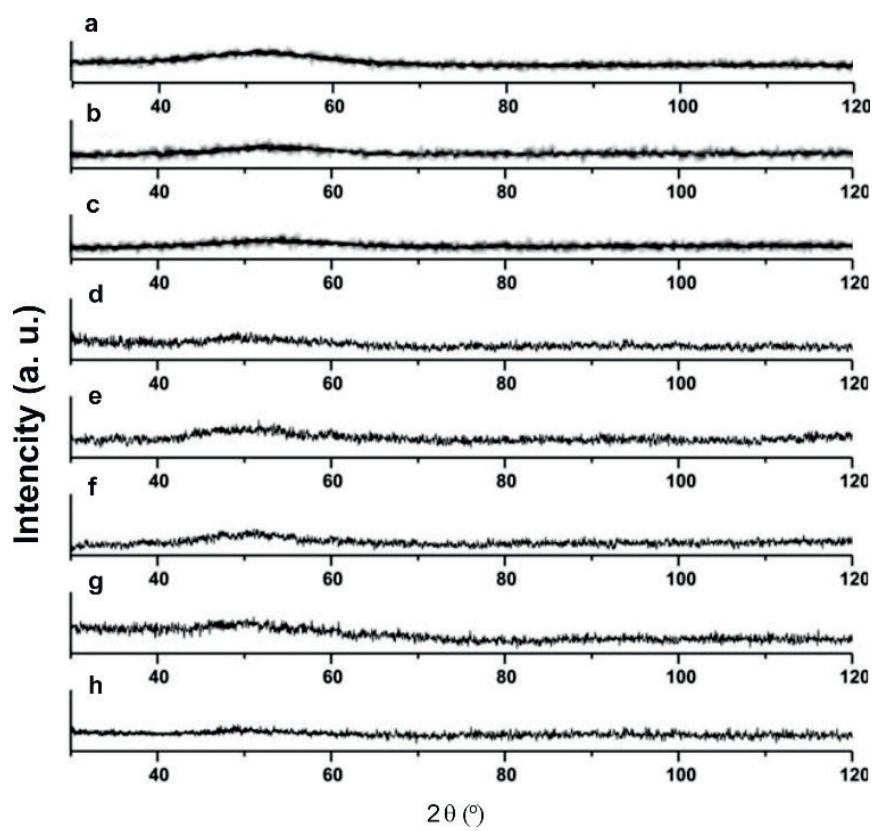

Fig. 1. X-ray diffraction patterns for the investigated samples: $\mathrm{Fe}_{61} \mathrm{Co}_{0} \mathrm{Zr}_{{ }_{+} \mathrm{x}} \mathrm{Hf}_{3-\mathrm{x}} \mathrm{W}_{2} \mathrm{Y}_{2} \mathrm{~B}_{20}$, where: a) $\mathrm{x}=1$, b) $\mathrm{x}=2$, c) $\mathrm{x}=3$; and

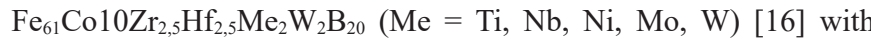
addition of: d) $\mathrm{Nb}$, e) $\mathrm{W}, \mathrm{f}$ ) $\mathrm{Ti}$, g) Mo, h) $\mathrm{Ni}$

All of the X-ray diffraction patterns, presented in Fig. 1, are typical for amorphous materials. Each pattern features one wide maximum, called an amorphous halo.

The DSC curves (for the temperature range from 750 to $1050 \mathrm{~K}$ ) are presented in Fig. 2 for the investigated samples of: $\mathrm{Fe}_{61} \mathrm{Co}_{10} \mathrm{Zr}_{2+\mathrm{x}} \mathrm{Hf}_{3-\mathrm{x}} \mathrm{W}_{2} \mathrm{Y}_{2} \mathrm{~B}_{20}$, (where: $\mathrm{x}=1,2$ or 3 ) and $\mathrm{Fe}_{61} \mathrm{Co}_{10} \mathrm{Zr}_{2.5} \mathrm{Hf}_{2.5} \mathrm{Me}_{2} \mathrm{~W}_{2} \mathrm{~B}_{20}(\mathrm{Me}=\mathrm{Ti}, \mathrm{Nb}, \mathrm{Ni}, \mathrm{Mo}, \mathrm{Y}, \mathrm{W})$ [20]. Analysis of the DSC curves allowed the determination of the thermal parameters; i.e. the: glass transition temperature $T g$, crystallisation onset temperature $T x$, melting temperature $T m$, and liquid state temperature $T l[21 \div 25]$. Using these values, the temperature range of the supercooled liquid $\Delta T x=T x-T g$ was determined [22, 24:28], in addition to the glass transition temperature $\operatorname{Trg}=\operatorname{Tg} / \operatorname{Tm}[22,29]$, and: $\operatorname{Tr} g=T g / T l, \Delta T m$ - the temperature range calculated from the difference $(=T l-T m)$ $[18,25]$, and the supercooled temperature $\Delta T l=T l-T x[19$, $26]$. The other determined parameters were the: modified glassforming ability parameter $(\mathrm{GFA}) \gamma m(=(2 T x-T g) / T l)[22,24]$, 
parameter $\gamma(=T x /(T g+T l))[22,29]$, and parameter $\delta(=T x /(T l$ - $T g$ )) [22]. All determined temperatures, temperature ranges and parameters describing glass-forming ability are presented in Tables 1, 2 and 3.

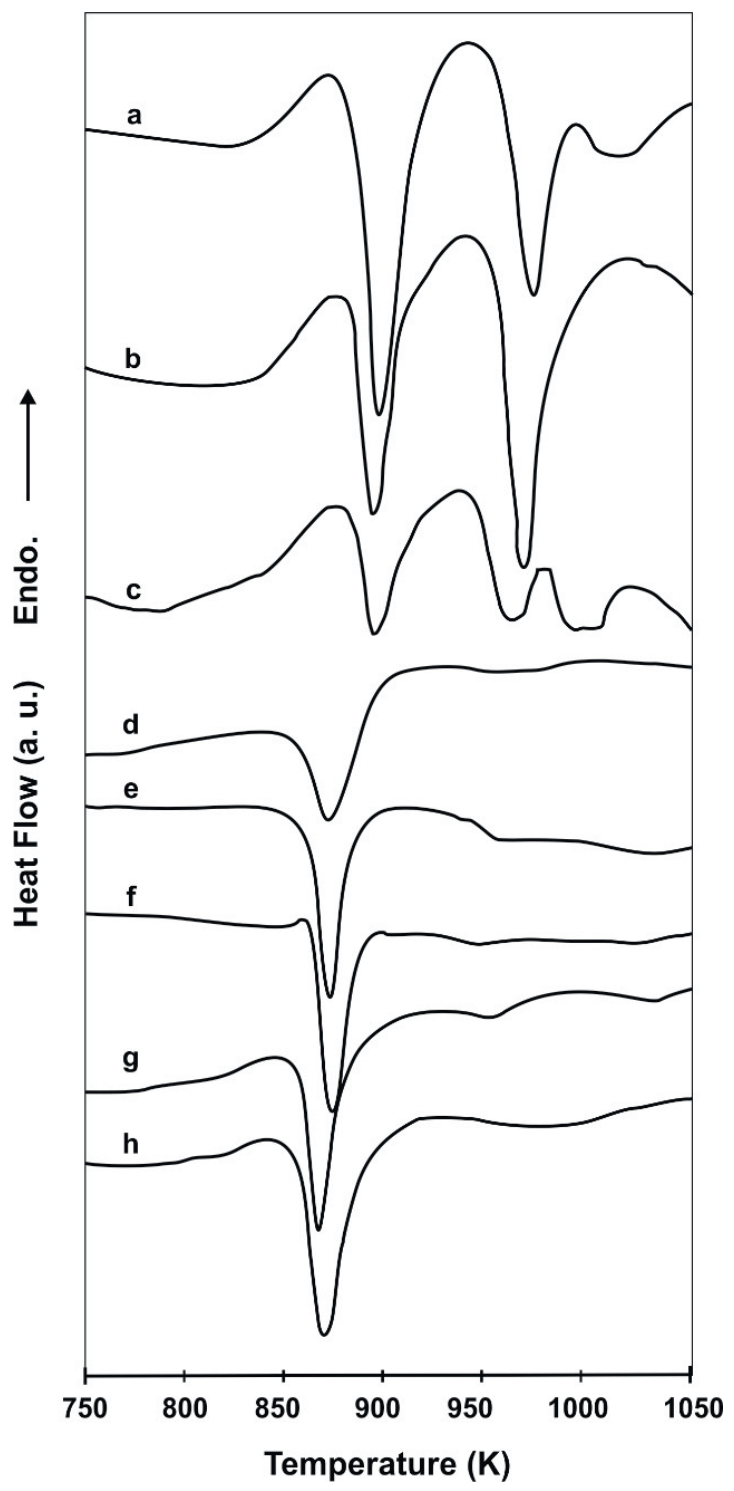

Fig. 2. DSC curves (over the temperature range from 750 to $1050 \mathrm{~K}$ ) for the samples of the investigated alloys: $\mathrm{Fe}_{61} \mathrm{Co}_{10} \mathrm{Zr}_{2+\mathrm{x}} \mathrm{Hf}_{3-\mathrm{x}} \mathrm{W}_{2} \mathrm{Y}_{2} \mathrm{~B}_{20}$, where: a) $\mathrm{x}=1, \mathrm{~b}) \mathrm{x}=2$, c) $\mathrm{x}=3$; and $\mathrm{Fe}_{61} \mathrm{Co}_{10} \mathrm{Zr}_{2.5} \mathrm{Hf}_{2.5} \mathrm{Me}_{2} \mathrm{~W}_{2} \mathrm{~B}_{20}$ $(\mathrm{Me}=\mathrm{Ti}, \mathrm{Nb}, \mathrm{Ni}, \mathrm{Mo}, \mathrm{Y}, \mathrm{W})$ [16] with addition of: d) $-\mathrm{Nb}, \mathrm{e})-\mathrm{W}$, f) $-\mathrm{Ti}, \mathrm{g})-\mathrm{Mo}, \mathrm{h})-\mathrm{Ni}$

TABLE 1

Characteristic temperatures for the investigated alloys, determined on the basis of the DSC curve analysis

\begin{tabular}{|c|c|c|c|c|}
\hline Composition of Alloy & $\begin{array}{c}\mathrm{Tg} \\
(\mathrm{K})\end{array}$ & $\begin{array}{c}\mathrm{Tx} \\
(\mathrm{K})\end{array}$ & $\begin{array}{c}\mathrm{Tm} \\
(\mathrm{K})\end{array}$ & $\begin{array}{c}\mathrm{Tl} \\
(\mathrm{K})\end{array}$ \\
\hline $\mathrm{Fe}_{61} \mathrm{Co}_{10} \mathrm{Zr}_{3} \mathrm{Hf}_{2} \mathrm{~W}_{2} \mathrm{Y}_{2} \mathrm{~B}_{20}$ & 837 & 888 & 1177 & 1503 \\
\hline $\mathrm{Fe}_{61} \mathrm{Co}_{10} \mathrm{Zr}_{4} \mathrm{Hf}_{1} \mathrm{~W}_{2} \mathrm{Y}_{2} \mathrm{~B}_{20}$ & 831 & 889 & 1122 & 1527 \\
\hline $\mathrm{Fe}_{61} \mathrm{Co}_{10} \mathrm{Zr}_{5} \mathrm{~W}_{2} \mathrm{Y}_{2} \mathrm{~B}_{20}$ & 819 & 889 & 1179 & 1468 \\
\hline $\mathrm{Fe}_{61} \mathrm{Co}_{10} \mathrm{Zr}_{2,5} \mathrm{Hf}_{2,5} \mathrm{Nb}_{2} \mathrm{~W}_{2} \mathrm{~B}_{20}$ & 788 & 885 & 1303 & 1450 \\
\hline $\mathrm{Fe}_{61} \mathrm{Co}_{10} \mathrm{Zr}_{2,5} \mathrm{Hf}_{2,5} \mathrm{~W}_{4} \mathrm{~B}_{20}$ & 813 & 871 & 1367 & 1493 \\
\hline $\mathrm{Fe}_{61} \mathrm{Co}_{10} \mathrm{Zr}_{2,5} \mathrm{Hf}_{2,5} \mathrm{Ti}_{2} \mathrm{~W}_{2} \mathrm{~B}_{20}$ & 794 & 859 & 1331 & 1488 \\
\hline $\mathrm{Fe}_{61} \mathrm{Co}_{10} \mathrm{Zr}_{2,5} \mathrm{Hf}_{2,5} \mathrm{Mo}_{2} \mathrm{~W}_{2} \mathrm{~B}_{20}$ & 790 & 838 & 1312 & 1462 \\
\hline $\mathrm{Fe}_{61} \mathrm{Co}_{10} \mathrm{Zr}_{2,5} \mathrm{Hf}_{2,5} \mathrm{Ni}_{2} \mathrm{~W}_{2} \mathrm{~B}_{20}$ & 771 & 840 & 1316 & 1494 \\
\hline
\end{tabular}

For all of the investigated alloys, it was possible to determine the glass-forming temperature $\mathrm{Tg}$. For the $\mathrm{Fe}_{61} \mathrm{Co}_{10} \mathrm{Zr}_{2+\mathrm{x}} \mathrm{Hf}_{3-\mathrm{x}} \mathrm{W}_{2} \mathrm{Y}_{2} \mathrm{~B}_{20}$ alloys (where: $\mathrm{x}=1,2$ or 3 ), the value of $T g$ was found to increase with increasing $\mathrm{Hf}$ content in the alloy. In the case of the $\mathrm{Fe}_{61} \mathrm{Co}_{10} \mathrm{Zr}_{2,5} \mathrm{Hf}_{2,5} \mathrm{Me}_{2} \mathrm{~W}_{2} \mathrm{~B}_{20}$ alloys, a decrease in the value of $\mathrm{Tg}$ was observed after the introduction of one of the following elements to the alloy: $\mathrm{Ti}, \mathrm{Nb}, \mathrm{Ni}, \mathrm{Mo}$ or $\mathrm{W}$. For samples from the first group, $\mathrm{Fe}_{61} \mathrm{Co}_{10} \mathrm{Zr}_{2+\mathrm{x}} \mathrm{Hf}_{3-\mathrm{x}} \mathrm{W}_{2} \mathrm{Y}_{2} \mathrm{~B}_{20}$ (where: $\mathrm{x}=1,2$ or 3 ), a complex crystallisation process consisting of two exothermic minima was observed. For the remaining alloys, the crystallisation process occurred in a single-stage. The difference between the crystallisation onset temperature $T x$ and the glass-transition temperature $T g$ determines the temperature range $\Delta T x$ of the supercooled liquid. For all but one of the investigated alloys, $\Delta T x$ was found to be equal to $50 \mathrm{~K}$; for the other alloy $\Delta T x$ was found to be $48 \mathrm{~K}$. Such a high value of the $\Delta T x$ range indicates a high value of glassforming ability for these bulk amorphous alloys in the form of plates of approximate thickness $0.5 \mathrm{~mm}$. Towards the higher temperatures, an endothermic feature (related to the onset of the melting process) was observed for all of the investigated alloys; this feature was denoted as $\mathrm{Tm}$. All of the studied alloys exhibited a wide range of $\Delta T m$. Referring to Fig. 3, for the Fe61Co10Zr2+xHf3-xW2Y2B20 alloys (where $\mathrm{x}=1,2$ or 3 ), the melting process occurred over a much wider temperature range (from $289 \mathrm{~K}$ to $405 \mathrm{~K}$ ) than for the alloys of $\mathrm{Fe}_{61} \mathrm{Co}_{10} \mathrm{Zr}_{2,5} \mathrm{Hf}_{2,5} \mathrm{Me}_{2} \mathrm{~W}_{2} \mathrm{~B}_{20}$, where $\mathrm{Me}=\mathrm{Ti}$, $\mathrm{Nb}, \mathrm{Ni}, \mathrm{Mo}, \mathrm{W}$ (from $126 \mathrm{~K}$ to $178 \mathrm{~K}$ ).

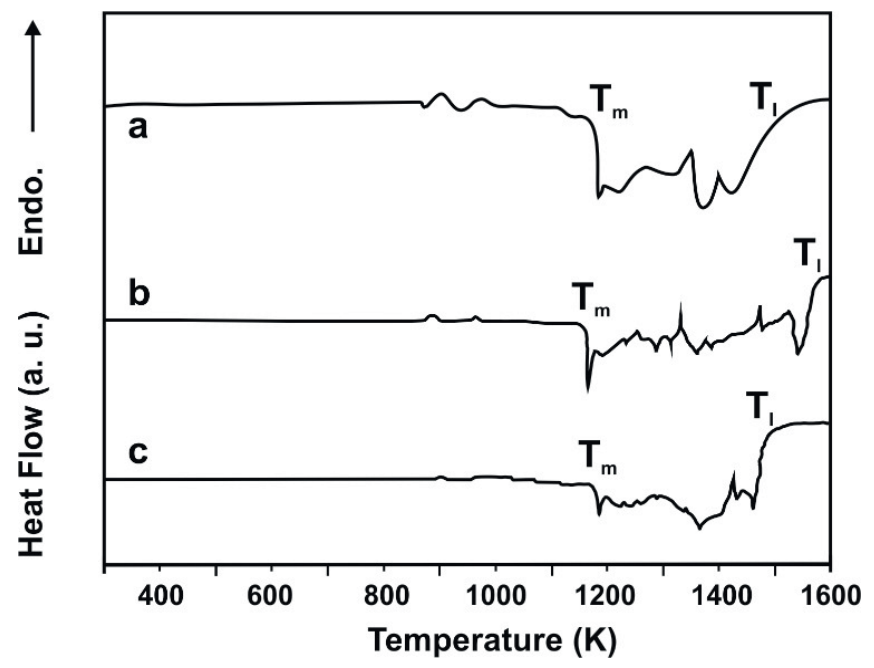

Fig. 3. Exemplar DCS curves, recorded for the $\mathrm{Fe}_{61} \mathrm{Co}_{10} \mathrm{Zr}_{2+\mathrm{x}} \mathrm{Hf}_{3-}$ ${ }_{x} \mathrm{~W}_{2} \mathrm{Y}_{2} \mathrm{~B}_{20}$ alloys (where $\mathrm{x}=1,2$ or 3 ) in the as-quenched state for samples in the form of plates of approximate thickness $0.5 \mathrm{~mm}(\mathrm{x}=1$ (a), $x=2$ (b) and $x=3(c))$

Referring again to Fig. 3, all of the curves feature at least two exothermic minima within the range from $\mathrm{Tm}$ to $\mathrm{Tl}$; this suggests that the alloys are outside the eutectic range.

According to data in [30], a large $\Delta T m$ range should suggest a low glass-forming ability, which is not true in the case of the investigated alloys. Taking into account the large difference between temperatures $T m$ and $T l$, large differences should be expected between the determined Trg parameter, based on the equations: $\operatorname{Tr} g=T x / T m$ and $T x / T l$ (Table 2). 
In Table 3, the three parameters determining glassforming ability according to [31-33]: $\gamma m, \gamma$ and $\delta$, have been gathered together with the value of supercooled liquid range, $\Delta \mathrm{Tx}$

Each of these parameters has a value indicating good glass- forming ability for the investigated bulk alloys.

\section{Discussion and conclusions}

In all of the investigated alloys, the glass-transition temperature $\mathrm{Tg}$ and the range of the supercooled liquid $\Delta T x$ temperature, were located below the crystallisation temperature of the alloys; this means that the investigated alloys are exhibiting very good thermal stability before the crystallisation process. It is well known that the bulk amorphous alloys are multicomponent alloys, consisting of a minimum of three elements. An increase in the number of components should improve their glass-forming ability, as a result of an increase in the number of possible different atomic configurations. In addition, the main elements should feature atomic radii that differ by at least $12 \%$ and be characterised by negative mixing heat [34]. The purpose of all the aforementioned criteria is to hinder long-distance atomic diffusion during the solidification process of the alloy; this, in turn, prevents the creation of long-range atomic interactions. In the $\mathrm{Fe}_{61} \mathrm{Co}_{10} \mathrm{Zr}_{2+x} \mathrm{Hf}_{3-x} \mathrm{~W}_{2} \mathrm{Y}_{2} \mathrm{~B}_{20}$ alloys, the lengths of the atom radii for $H f$ and $Z r$ are the same $(0.155 \mathrm{~nm})$; therefore responsibility for the change in width of the supercooled liquid range lies with the change in content of these elements in the alloy. It can be stated that, within the investigated change in content of $H f$ and $\mathrm{Zr}$ in the alloys, a decrease in the width of the supercooled liquid range was observed with increasing Hf content. For the rest of the investigated alloys, no correlation was found in relation to the width of the supercooled liquid range $\Delta T x$. In general, a broad supercooled liquid range should be connected with good glass-forming ability, [35], and should be in agreement with the determined $T_{r g}$ parameter. The latter is used to specify glass- forming ability. It should be mentioned that the analysed alloys possess relatively broad $\Delta T_{m}$ ranges, which could suggest that the alloys are outside their eutectic ranges. The $T g$ parameter is not strongly dependent on minor changes in the alloy composition, whereas the $T l$ parameter is highly influenced by this. It is well known that good glassforming ability is observed for alloys that are close to their eutectic range. According to Turnbull, the major criterion for determining $\operatorname{Trg}$ is that the value of $\operatorname{Tr} g$ should be equal to 0.66 for the ratio $T g / T 1$. According to other authors, [36], a better way of determining the value of the Trg parameter is to use the $\mathrm{Tg} / \mathrm{Tm}$ ratio. Unfortunately, as has been shown in $[37,38]$, a glass transition temperature $\operatorname{Trg}$ that has been calculated in this way doesn't reveal any differences between each of the bulk amorphous alloys. In the case of $\operatorname{Tr} g=(T g / T l)$ there is a good correlation with the glassforming ability for the bulk amorphous alloys. According to Turnbull's assumptions, neither of the investigated alloys fulfils the dependency $\operatorname{Trg} \geq 2 / 3$. From the DSC measurements for the exemplar FeCoB-based alloys, the relation $\operatorname{Tr} g=T g / T m \geq 2 / 3$ is fulfilled for the samples, where the softening process (from temperature $\mathrm{Tm}$ to temperature $T l$ ) occurs in stages over a wide temperature range - which

TABLE 2

Parameters $\operatorname{Trg} 1$ and $\operatorname{Trg} 2$ and the temperature ranges: $\Delta T m$ and $\Delta T l$

\begin{tabular}{|c|c|c|c|c|}
\hline Alloy composition & $\mathrm{T}_{\mathrm{rg} 1}=\mathrm{T}_{\mathrm{g}} / \mathrm{T}_{\mathrm{m}}$ & $\mathrm{T}=\mathrm{T}_{\mathrm{g}} / \mathrm{T}_{1}$ & $\begin{array}{c}\Delta T m \\
(\mathrm{~K})\end{array}$ & $\begin{array}{l}\Delta T l \\
(\mathrm{~K})\end{array}$ \\
\hline $\mathrm{Fe}_{61} \mathrm{Co}_{10} \mathrm{Zr}_{3} \mathrm{Hf}_{2} \mathrm{~W}_{2} \mathrm{Y}_{2} \mathrm{~B}_{20}$ & 0.71 & 0.56 & 325 & 615 \\
\hline $\mathrm{Fe}_{61} \mathrm{Co}_{10} \mathrm{Zr}_{4} \mathrm{Hf}_{1} \mathrm{~W}_{2} \mathrm{Y}_{2} \mathrm{~B}_{20}$ & 0.74 & 0.54 & 405 & 637 \\
\hline $\mathrm{Fe}_{61} \mathrm{Co}_{10} \mathrm{Zr}_{5} \mathrm{~W}_{2} \mathrm{Y}_{2} \mathrm{~B}_{20}$ & 0.69 & 0.56 & 289 & 578 \\
\hline $\mathrm{Fe}_{61} \mathrm{Co}_{10} \mathrm{Zr}_{2,5} \mathrm{Hf}_{2,5} \mathrm{Nb}_{2} \mathrm{~W}_{2} \mathrm{~B}_{20}$ & 0.60 & 0.54 & 147 & 565 \\
\hline $\mathrm{Fe}_{61} \mathrm{Co}_{10} \mathrm{Zr}_{2,5} \mathrm{Hf}_{2,5} \mathrm{~W}_{4 \mathrm{~B}_{20}}$ & 0.59 & 0.54 & 126 & 680 \\
\hline $\mathrm{Fe}_{61} \mathrm{Co}_{10} \mathrm{Zr}_{2,5} \mathrm{Hf}_{2,5} \mathrm{Ti}_{2} \mathrm{~W}_{2} \mathrm{~B}_{20}$ & 0.59 & 0.53 & 157 & 694 \\
\hline $\mathrm{Fe}_{61} \mathrm{Co}_{10} \mathrm{Zr}_{2,5} \mathrm{Hf}_{2,5} \mathrm{Mo}_{2} \mathrm{~W}_{2} \mathrm{~B}_{20}$ & 0.60 & 0.54 & 150 & 624 \\
\hline $\mathrm{Fe}_{61} \mathrm{Co}_{10} \mathrm{Zr}_{2,5} \mathrm{Hf}_{2,5} \mathrm{Ni}_{2} \mathrm{~W} 2 \mathrm{~B}_{20}$ & 0.58 & 0.52 & 178 & 654 \\
\hline
\end{tabular}

TABLE 3

Parameters determining glass-forming ability: $\gamma m, \gamma$ and $\delta$ and value of supercooled liquid range, $\Delta \mathrm{Tx}$

\begin{tabular}{|c|c|c|c|c|}
\hline \hline Alloy composition & $\begin{array}{c}\Delta T_{x} \\
(\mathrm{~K})\end{array}$ & $\gamma_{m}$ & $\gamma$ & $\delta$ \\
\hline $\mathrm{Fe}_{61} \mathrm{Co}_{10} \mathrm{Zr}_{3} \mathrm{Hf}_{2} \mathrm{~W}_{2} \mathrm{Y}_{2} \mathrm{~B}_{20}$ & 51 & 0.62 & 0.38 & 1.33 \\
\hline $\mathrm{Fe}_{61} \mathrm{Co}_{10} \mathrm{Zr}_{4} \mathrm{Hf}_{1} \mathrm{~W}_{2} \mathrm{Y}_{2} \mathrm{~B}_{20}$ & 58 & 0.62 & 0.38 & 1.28 \\
\hline $\mathrm{Fe}_{61} \mathrm{Co}_{10} \mathrm{Zr}_{5} \mathrm{~W}_{2} \mathrm{Y}_{2} \mathrm{~B}_{20}$ & 70 & 0.65 & 0.39 & 1.37 \\
\hline $\mathrm{Fe}_{61} \mathrm{Co}_{10} \mathrm{Zr}_{2,5} \mathrm{Hf}_{2,5} \mathrm{Nb}_{2} \mathrm{~W}_{2} \mathrm{~B}_{20}$ & 97 & 0.67 & 0.39 & 1.33 \\
\hline $\mathrm{Fe}_{61} \mathrm{Co}_{10} \mathrm{Zr}_{2,5} \mathrm{Hf}_{2,5} \mathrm{~W}_{4} \mathrm{~B}_{20}$ & 58 & 0.62 & 0.35 & 1.31 \\
\hline $\mathrm{Fe}_{61} \mathrm{Co}_{10} \mathrm{Zr}_{2,5} \mathrm{Hf}_{2,5} \mathrm{Ti}_{2} \mathrm{~W}_{2} \mathrm{~B}_{20}$ & 65 & 0.62 & 0.37 & 1.24 \\
\hline $\mathrm{Fe}_{61} \mathrm{Co}_{10} \mathrm{Zr}_{2,5} \mathrm{Hf}_{2,5} \mathrm{Mo}_{2} \mathrm{~W}_{2} \mathrm{~B}_{20}$ & 48 & 0.60 & 0.37 & 1.24 \\
\hline $\mathrm{Fe}_{61} \mathrm{Co}_{10} \mathrm{Zr}_{2,5} \mathrm{Hf}_{2,5} \mathrm{Ni}_{2} \mathrm{~W}_{2} \mathrm{~B}_{20}$ & 69 & 0.60 & 0.37 & \\
\hline
\end{tabular}


is not in agreement for alloys close to their eutectic range. In the investigated materials (Fig. 3), the temperature range $\triangle T m$ is wide and equal to: $289 \mathrm{~K}, 405 \mathrm{~K}$ and $325 \mathrm{~K}$ for the alloys $\mathrm{Fe}_{61} \mathrm{Co}_{10} \mathrm{Zr}_{5} \mathrm{~W}_{2} \mathrm{Y}_{2} \mathrm{~B}_{20}, \quad \mathrm{Fe}_{61} \mathrm{Co}_{10} \mathrm{Zr}_{4} \mathrm{Hf}_{1} \mathrm{~W}_{2} \mathrm{Y}_{2} \mathrm{~B}_{20}$, and $\mathrm{Fe}_{61} \mathrm{Co}_{10} \mathrm{Zr}_{3} \mathrm{Hf}_{2} \mathrm{~W}_{2} \mathrm{Y}_{2} \mathrm{~B}_{20}$, respectively. According to [30, 33], this wide range of $\Delta \mathrm{T}_{\mathrm{m}}$ should indicate poor glass-forming ability; however, as could be seen from the DSC results, it hasn't had a significant influence on the GFA of the investigated alloys. This is why, when choosing a method for calculating $T_{r g}$, it is very important to investigate a group of alloys systematically; especially for alloys with different thicknesses - in which the quenching process is proceeding in different ways. This is connected with the production process itself and the microstructure of the alloys. It should be noted that the majority of parameters which allow the determination of glass-forming ability (Table 3 ) have been calculated based on the temperature $T_{l}$, which is strongly connected with the glass-forming ability of the bulk metallic glasses. Moreover, in the investigated alloys, the value of the supercooled liquid temperature range is greater than $50 \mathrm{~K}$. According to [39 - 41], this suggests that the investigated alloys are characterised by a good GFA. In addition, the glass transition temperature $T_{g}$ for each of the investigated alloys was successfully determined, which indicates the good thermal stability of the alloys before the crystallisation process.

\section{REFERENCES}

[1] D. Turnbull, Contemp. Phys. 10, 473 (1969).

[2] H. A. Davies, Phys. Chem. Glasses. 17, 159-173 (1976).

[3] D. R. Uhlmann, J. Non-Crystal. Solids. 7, 337 (1972).

[4] K. Błoch, J. Magn. Magn. Mater. 390, 118-122 (2015).

[5] M. Nabiałek, J. Alloys and Compd. 642, 98-103 (2015).

[6] A. Lukiewska, J. Zbroszczyk, M. Nabialek, J. Olszewski, J. Swierczek, W. Ciurzynska, K. Sobczyk, M. Dospial, Arch. Metall. Mater. Sci. 53, 881 (2008).

[7] K. Gruszka, Mater. Technol. 50 (5), 707-718 (2016).

[8] C. C. Lavorato, G. Fiore, P. Tiberto, M. Baricco, H. Sirkin, J. A. Moya, J. Alloys Compd. 536S, S319-S323 (2012).

[9] K. Błoch, M. Nabiałek, Acta Phys. Polon. A, 127, 413 (2015).

[10] H. Chiriac, N. Lupu, Mater. Sci. Eng. A 375-377, 255-259 (2004).

[11] D. Szewieczek, S. Lesz, J. Mater. Process. Tech. 162, 254-259 (2005).

[12] M.G. Nabialek, M. Szota, M.J. Dospial, J. Alloys Compd. 526, 68-73 (2012).

[13] M. Nabiałek, P. Pietrusiewicz, M. Dośpiał, M. Szota, J. Gondro, K. Gruszka, A. Dobrzańska-Danikiewicz, S. Walters, A. Bukowska, J. Alloys Compd. 615, S56-S60 (2015).

[14] H.S. Chen, D. Turnbull, Acta Metallurgica 17, 1021-1031
(1969).

[15] Gilman, J. J. Metallic glasses. Science (New York, N.Y.) 208, 856-61 (1980).

[16] Z. Shao, J. P. Singer, Y. Liu, Z. Liu, H. Li, M. Gopinadhan, C. S. O’Hern, J. Schroers, Ch. O. Osuji, Physical Rewiew E 91, 020301(R) (2015).

[17] H. S. Chen and D. Turnbull, J. Chem. Phys. 48, 12560 (1968).

[18] C. A. Angell, Science 267, 1924-1935 (1995).

[19] Z. P. Lu, H. Tan, Y. Li, S. C. Ng, Scripta Mater. 42, 667-673 (2000).

[20] M. Nabiałek, M. Dośpiał, M. Szota, P. Pietrusiewicz, J. Jędryka, J. Alloys Compd. 509, 3382-3386 (2011).

[21] L.Wang, Q. Zhang, X. Cui, F. Zu, J. Non. Cryst. Solids 419, 51-57 (2015).

[22] M. Nabiałek, J. Zbroszczyk, W. Ciurzyńska, J. Olszewski, S. Lesz, P. Brągiel, J. Gondro, K. Sobczyk, A. Łukiewska, J. Świerczek, P. Pietrusiewicz, Arch. Metall. Mater 55, 195-203 (2010).

[23] K. Q. Qui, H. F. Zhang, A. M. Wang, B. Z. Ding, Z. Q. Hu, Acta Materialia 70, 3567-3578 (2002).

[24] R. Li, S. Kumar, S. Ram, M. Stoica, S. Roth, J. Eckert, J. Phys. Appl. Phys. 42, 085006 (2009).

[25] W.M. Wang, A. Gebert, S. Roth, U. Kuehn, L. Schultz, J. Alloys Compd. 459, 203-208 (2008).

[26] A. Makino, T. Kubota, Ch. Chang, M. Makabe, A. Inoue, J. Magn. Magn. Mater. 320, 2499-2503 (2008).

[27] X.D. Wang, J.Z. Jiang, S. Yi, J. Non-Cryst. Solids 353, $4157-$ 4161 (2007).

[28] T. Kozieł, J. Latuch, A. Zielińska-Lipiec, Arch. Metall. Mater. 58, 601-605 (2013).

[29] S. F. Guo, Z. Y. Wu, L. Liu, J. Alloys and Compd. 468, 54-57 (2009).

[30] L.C. Zhang, J. Xu, Journal of Non - Crystalline Solids 347, 166-172 (2004).

[31] B. Yao, Y. Zhang, L. Si, H. Tan, Y. Li, Journal of Physics Condensed Matter 16, 6325-6334 (2004).

[32] B. A. Sun, M. X. Pan, D. Q. Zhao, W. H. Wang, X. K. Xi, M T. Sandor, Y. Wu, Scriota Materialia 59, 1159-1162 (2008).

[33] S. Roth, W. Loeser, J. Mater. Sci. Lett. 5,1033 - 1035 (1986).

[34] A. Inoue, Acta. Mater. 48, 279-306 (2000).

[35] A. Inoue, Mater. Trans. Japan. Inst. Metals 36, 866 (1995).

[36] C. Thompson, A. L. Greer, F. Spaepen, Acta Metall. 31, 1883 (1983).

[37] ZP Lu, H. Tan, Y. Li, SC Ng, J. Non-Cryst. Solids 270, 103 (2000).

[38] Y. Li, SC. Ng, CK Ong, HH Hng, TT. Goh, Scripta Mater. 36, 783 (1997).

[39] Y. He, CE Price, S. J. Poon, Philos. Mag. Lett. 70, 371 (1994).

[40] K. Biswas, S. Venkataraman, W. Y. Zhang, S. Ram, J. Eckert, J. Appl. Phys. 100, 023501 (2006).

[41] S. Lesz, R. Babilas, R. Nowosielski, Diff. and Def. Data Pt. B: Solid St. Phenom. 203-204, 296-301 (2013). 
